\title{
Efficient Thermal Insulation of Passive House with Curved Façades in Cold Climate
}

\author{
Askar Aznabaev ${ }^{1, *}$, Ivan Pshuk $^{1}$, Daria Likhaia ${ }^{1}$, Semen Bondarenko ${ }^{1}$, Kirill Gureev ${ }^{1}$ and \\ Sergey Amelchenko ${ }^{1}$ \\ ${ }^{1}$ Peter the Great St. Petersburg Polytechnic University, 195251 Politekhnicheskaya, 29, \\ Saint-Petersburg, Russia
}

\begin{abstract}
In this paper there is exploration of the possibility of creating effective sealed building envelope in zero energy building (ZEB) with unique façades. This article describes passive and active measures of decrease of thermal loss through enclosure structures, usage of modern insulation materials; positive effect of rationalization of the façade orientation and form of a building in a plan; on the base of existing architecture concept structural solutions of building envelope are suggested. Using thermal FEA the enclosure structure was optimized. The results of modeling of units and elements of building envelope are: heat transfer coefficient $U$-value for heterogeneous multilayer structure, picture of temperature distribution and magnitude of the thermal conductivity and temperature of internal wall surface.
\end{abstract}

\section{Introduction}

According to Kyoto Protocol [1], more than 140 industrialized countries have committed themselves to substantially reduce $\mathrm{CO}_{2}$ emissions. So countries have decided that the use of energy-saving technologies is a priority in order to preserve our natural resources.

The building sector is responsible for $40 \%$ of total energy consumption and $\mathrm{CO}_{2}$ emissions in the world. That is why there is a necessity of a new approach to the design of each new project and each of the reconstructed building. E. Enache-Pommer, R. Mayer and G. Parsons write [2], that all over the world emissions of hydrocarbons can be reduced by 715 million TFOE by improving energy efficiency in buildings $(27 \%$ of the projected increase in greenhouse gas emissions).

The most rapidly developing direction of the construction was the design of buildings with low energy consumption in the 1990's, according to paper [3]. In 1988, W. Feist and B. Adamson formulated in their book [4] theory of passive houses, which describes the principles of energy-efficient buildings. The articles $[5,6]$ mention that main requirement is the creation of a highly efficient building envelope. This is achieved through detailed design of exterior walls with a large layer of insulation. The tightness of the building envelope is provided by low air permeability and the lack of thermal bridges. This is

\footnotetext{
* Corresponding author: askar.spbstu@gmail.com
} 
noticed in the articles [7-9] written by T.S. Egorova, S.G. Sheina, A.A. Fedotova and others authors.

One of the best complex approaches for the design of a passive house is the use of passive measures, which rationalizes the use of insulating materials. According to $\mathrm{V}$. Murgul,

N. Vatin, E.H. Varzaneha [10-12], it includes: increased a compact shape of the building, the preferred orientation of windows and building façades to the south to provide solar heat gains. All these activities and recommendations for the design joint of building envelopes by the Passive House Institute restrict architects and designers. From an architectural point of view, the vast majority of buildings with zero energy consumption has a simple shape like a square or cylinder. The theory of the passive house limits future building projects in their forms of expression and a variety of architectural façades.

Recently, there is a complex task for the team of architects and designers. The complexity of its implementation consists in two aspects. On the one hand there is a need to create an unusual religious architecture of the building. On the other hand, the project shall conform to the requirements of energy efficiency. It is mentioned in article [13]. Thus the use of non-standard design solutions for passive house is not possible. Project teams need to find a balance between architectural concepts and solutions related to energy efficiency.

In this paper we consider the possibility of creating energy efficient sealed envelope for a unique building. This article describes the features of solutions used in a building with architectural expressive and complex façades of the nZEB.

The object of study is a concept architectural project, created by students of the SPbPU for the international competition "Multi-comfort House ISOVER-2015". It is noted in article [14] that the project involves a high degree of architectural study and detailed design of the building envelope.

The paper has the following goals and objectives:

- analysis of the shape and envelope of an existing architectural project from the viewpoint of energy efficiency and the definition of geometrical parameters,

- offer passive measures to reduce heat loss through the building envelope with rationalization of its shape and orientation of the façades,

- selection of the optimal type of building envelope and wall structure and the construction of individual nodes and elements of building enclosure with a continuous insulation layer,

- thermal modeling, analysis and determination of thermal properties of previously designed nodes of the heterogeneous building envelope.

Nomenclature

$\begin{array}{ll}\text { nZEB } & \text { near-zero energy building } \\ \text { FEA } & \text { finite element analysis } \\ \text { TFOE } & \text { tonnes of fuel oil equivalent } \\ \text { f-factor } & \text { form factor (perimeter to area ratio) } \\ \text { LSTWC } & \text { light steel thin-walled construction }\end{array}$

\section{Methods}

\subsection{Passive action to reduce heat loss through the building envelope}

The initial data for the study are presented in the form of digital conceptual 3D-building model created in Revit. In addition, the projected building is located in Astana, Kazakhstan. 
This area has a sharply continental climate and as a result strong winds. Number of windy days is 280-300 per year. These factors can have a significant impact on the overall thermal resistance. High wind pressure on the façade is the cold air infiltration into the room. These factors must be considered when the architecture of the building façades is designed.

Exploration of the initial architectural model has revealed negative factors which increase the heat loss through the building envelope:

- non-compact form caused by multisection structure of the building (Fig. 1a),

- vertical irregularity of enclosure construction (Fig. 1b),

- increased area of translucent structures as part of the façades,

- large number of terraces with accessible roof (Fig. 1a).

a)

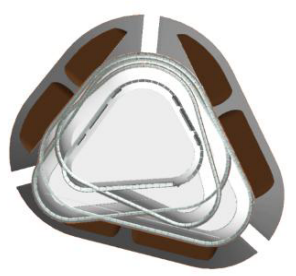

b)

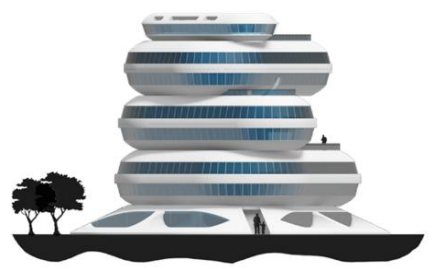

c)

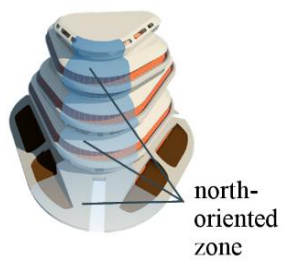

Fig. 1. General view of the building: (a) plan, (b) south façade, (c) perspective from North.

To minimize the negative impact of these factors the measures that do not change the original architecture of the project have been suggested. Among them the following are:

- horizontal rotation of major sections of the building to reduce the total façades' area oriented to the north (Fig. 1c),

- orientations of terraces and the extended side of façades to the southern direction for maximizing solar heat gains and insolation (Fig. 1a).

Also, during the analysis the positive moments in a curvilinear configuration of façades were revealed. In the plan the triangle deprived of corners due to bionic modification (Fig. 1a). Firstly, such form has f-factor $=0,93$ that is $12-14 \%$ less, than for traditional rectangular in plan of a building. Secondly, rounded building shapes chosen due to the aerodynamic properties reduce the wind pressure upon a wall (Fig. 2a). Therefore, the air infiltration through a building cover is passively reduced. Thirdly, trilateral configuration of façades provides their natural day lighting. Thus the relative area of the unlit façades is $25 \%$ less (Fig. 2b) than for traditional. In summary, the cover of a façade has no corners, thereby excludes undesirable thermal bridges.

a)

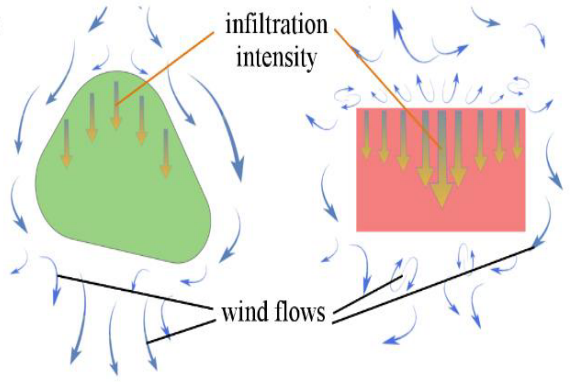

b)

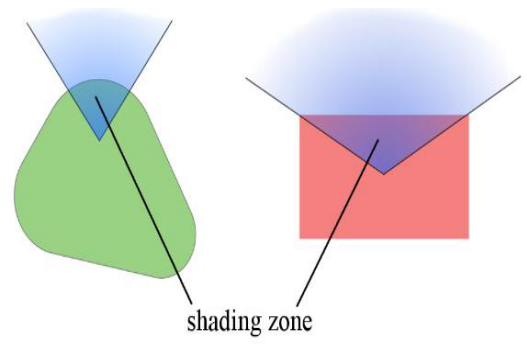

Fig. 2. Comparison of building forms in the plan of: (a) the perception of wind pressure, (b) the level of daylight illumination. 


\subsection{Special aspects of designing the effective building envelope}

To choose the type of enclosure walls and to appoint its level of thermal performance it is needed to consider two main factors:

- climatic conditions of the area,

- features of the architecture and shape of the façades.

Long heating period (216-229 days/year) is one of reasons for constructing walls with heat transfer coefficient $\mathrm{U} \leq 0.1 \mathrm{~W} /\left(\mathrm{m}^{2} \cdot \mathrm{K}\right)$. On this basis framed type of walls were chosen for designing building. Space frame of walls is formed with flat trusses [15] that repeat geometry of concept architecture project (Fig. 3a). Applying LSTWC allows to minimize weight of enclosure constructions (Fig. 3c).

Besides that, fulfilling the frame with effective insulation gives a wall with high thermal resistance [16]. The important point in designing of insulated frame is to form ongoing layer of insulation through the whole cross-section of building. It can be achieved by complete isolation of supporting reinforced concrete elements of the environment and by setting up mutual arrangement of 4-ply insulation with the displacement. The frame of enclosure walls is designed as whole curtain and does not have thermal bridges at the junction of adjacent floors and in interface assembly of roof and wall (Fig. 3b).

a)

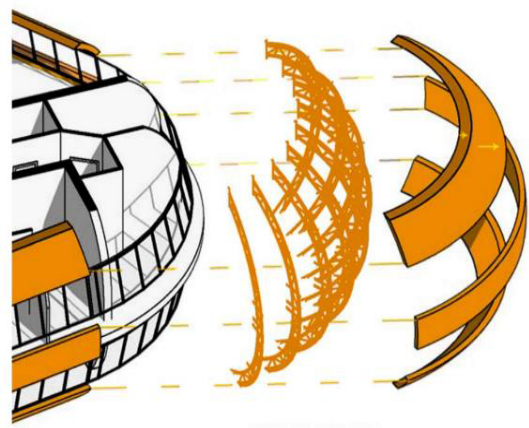

b)

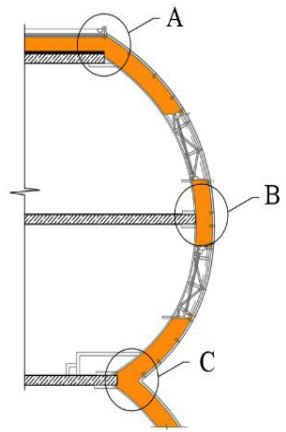

c)

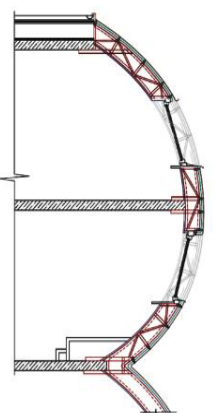

Fig. 3. (a) spatial model of the building envelope, (b) arrangement of insulation layer in cross section, (c) profile of bearing framework (truss).

Obtaining the most adequate value of coefficient of heat transfer is reached by detail analysis of processes of thermal conductivity in heterogeneous and complicated assembles of construction [17].

This research focuses on the development of FEA and of thermal 2D modeling . Construction of assembles was created in AutoCAD. After that thermal valuations were calculated in THERM software.

For analyzing boundary conditions were set (Tab. 1) which are regulated by National standards of buildings thermal protection and microclimate in internal building spaces [19]. 
Table 1. Boundary conditions for thermal analysis of enclosing structures.

\begin{tabular}{|l|c|c|c|}
\hline \multicolumn{1}{|c|}{ Performance } & Notation & $\begin{array}{c}\text { Units of } \\
\text { measurements }\end{array}$ & Value \\
\hline $\begin{array}{l}\text { Heat transfer coefficient of wall surfaces: } \\
\text { 1. inside } \\
\text { 2. outside }\end{array}$ & $\begin{array}{c}\alpha_{\text {in }} \\
\alpha_{\text {out }}\end{array}$ & $\begin{array}{r}{\left[\mathrm{W} /\left(\mathrm{m}^{2} \cdot \mathrm{K}\right)\right]} \\
{\left[\mathrm{W} /\left(\mathrm{m}^{2} \cdot \mathrm{K}\right)\right]}\end{array}$ & $\begin{array}{c}8.7 \\
23.0\end{array}$ \\
\hline $\begin{array}{l}\text { Optimum relative humidity of the indoor air in the cold } \\
\text { season }\end{array}$ & $W_{\text {in }}$ & {$[\%]$} & 45.0 \\
\hline Outdoor air humidity & $W_{\text {ext }}$ & {$[\%]$} & 65.0 \\
\hline Optimum indoor temperature & $t_{\text {in }}$ & {$\left[{ }^{\circ} \mathrm{C}\right]$} & +21.0 \\
\hline $\begin{array}{l}\text { Outdoor temperature (average temperature } \\
\text { of the coldest five-day period per year) }\end{array}$ & $t_{\text {out }}$ & {$\left[{ }^{\circ} \mathrm{C}\right]$} & -33.0 \\
\hline Absolute minimum temperature & $t_{\min }$ & {$\left[{ }^{\circ} \mathrm{C}\right]$} & -52.0 \\
\hline Absolute maximum temperature & $t_{\max }$ & {$\left[{ }^{\circ} \mathrm{C}\right]$} & +45.0 \\
\hline Average outdoor temperature of the heating season & $T_{\text {ave }}$ & {$\left[{ }^{\circ} \mathrm{C}\right]$} & -8.4 \\
\hline $\begin{array}{l}\text { Dew point temperature is taken on the basis } \\
\text { of the abovementioned preset conditions }\end{array}$ & $t_{d}$ & {$\left[{ }^{\circ} \mathrm{C}\right]$} & +8.6 \\
\hline
\end{tabular}

\section{Results}

\subsection{Effect of passive measures}

At the base of project documentation (Fig. 4a) and of simulation of solar activity using Autodesk Ecotect Analysis software for Astana city, Kazakhstan, energy optimum location of a building was determined. Analysis is based on average daily incident radiation on a vertical surface. Major solar heat gains are reached by orientation of façades on the angle of $160^{\circ}$ (direction SSE) (Fig. 4b). Due to obtained data and rotation of building sections (Fig. 4c) optimal orientation of the building as regards energy rationality was achieved.

a)

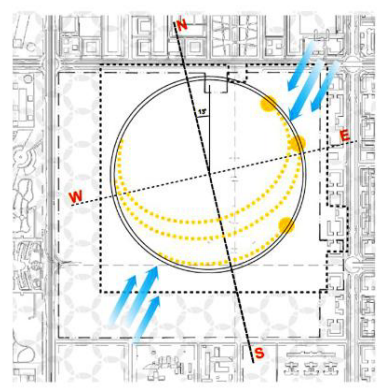

b)

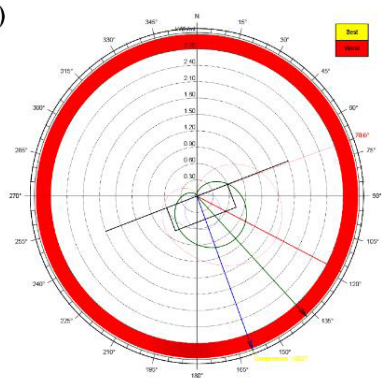

c)

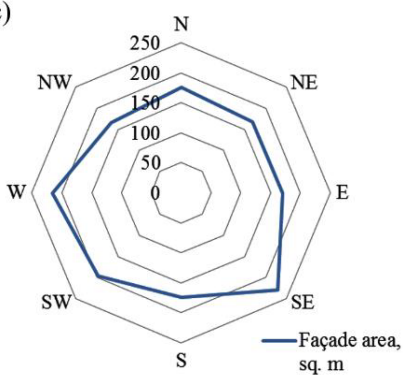

Fig. 4. (a) climatic conditions of building site, (b) diagram of optimum building orientation, (c) ratio of the façade areas to the cardinal directions.

\subsection{Thermal analysis of interface nodes of enclosure structures}

Structural solutions of building envelope that were demanded were optimised to exclude through-the-thickness thermal bridges. Three assembles of roof, wall and slab-A, B and C (Fig. 3b) were exposed to comprehensive thermal analysis. For some of them there are following pictures:

- structure scheme and composition of optimized (Fig. 5a,c),

- picture of temperature distribution in envelope (Fig. 5b), 
- minimal temperature in interior surface of enclosure structure (Fig. 5d).

a)

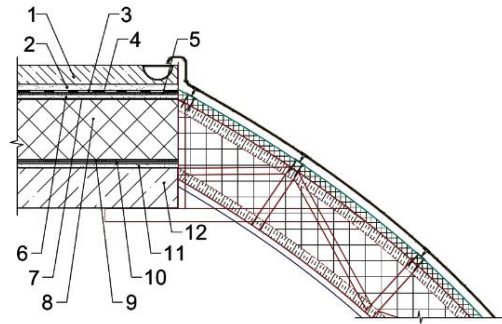

c)

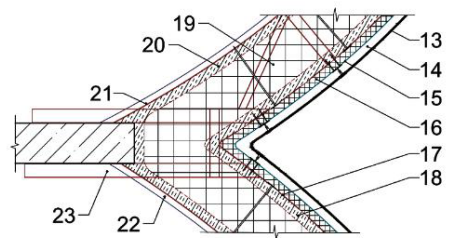

b)

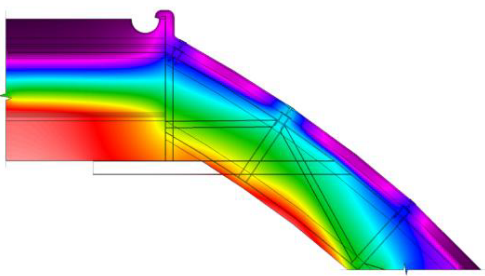

d)

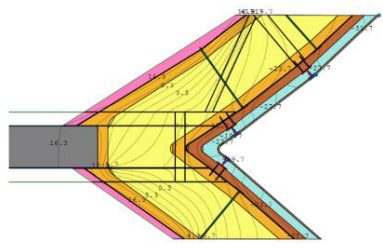

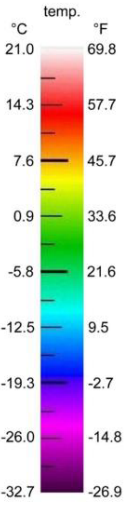

Fig. 5. $(\mathrm{a}, \mathrm{c})$ constructive drawings of nodes $\mathrm{A}$ and $\mathrm{C}$, (b) color infrared picture of the temperature distribution in node $\mathrm{A},(\mathrm{c})$ temperature distribution in node $\mathrm{C}$.

It has to be admitted, that relative thickness of effective insulation composes $\sim 90 \%$ or $390 \mathrm{~mm}$. It indicates low material consumption of building and rationality of design solution. Materials that are used in enclosure structures and its thickness are restricted in appendix A.

Modeling shown that in unfavorable climate conditions temperature of interior wall surface $t_{\text {int }}^{\text {surf }}=+16.3^{\circ} \mathrm{C}$ (indoor air temperature $t_{\text {int }}=+20.0^{\circ} \mathrm{C}$ ). It satisfies requirements ISO $7730[20,21]$.

Main characteristic of energy efficiency and structure comfort is airtightness of building envelope. Its numerical rating is air permeability, occurrence of thermal bridges and intensity of thermal loss through it. According to multistage thermal analysis and optimization of envelope construction, the fact that it is better to locate all supporting parts inside a building was determined. There are only metal profiles of LSTWC as thermally conductive inclusions. Thus due to high thickness and thermal lag of walls and thinness of metal profiles influence of heat transfer through metal frame is insignificant (Fig. 6).

a)

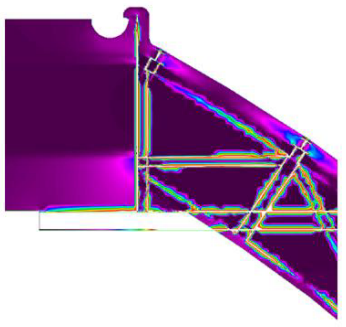

b)

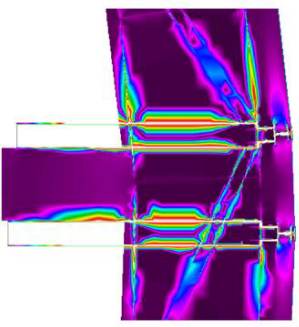

c)

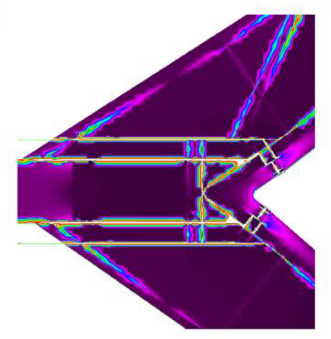

Heat loss, $\mathrm{W} / \mathrm{m}^{2}$

500

375

250

125

0

Fig. 6. Magnitude of heat transfer through envelope structures in assembles: (a) A, (b) B and (c) C.

Values of U-factor that was calculated for assembles of heterogeneous multilayer structure and translucent constructions in THERM software are described in table 2.

On the base of taken wall construction and concept building model energy balance of the object was calculated in Multi-Comfort Designer software that was certified by Passive House Institute. The results are shown in table 3. 
Table 2. Results of calculating U-value of enclosure structures.

\begin{tabular}{|l|c|}
\hline \multicolumn{1}{|c|}{ Thermal transmittance } & $\mathrm{U},\left[\mathrm{W} /\left(\mathrm{m}^{2} \cdot \mathrm{K}\right)\right]$ \\
\hline Walls & 0.089 \\
\hline Roof & 0.098 \\
\hline Slab above the basement & 0.109 \\
\hline Windows & 0.769 \\
\hline Doors & 0.714 \\
\hline
\end{tabular}

Table 3. Numerical energy balance characteristics of building.

\begin{tabular}{|c|c|c|}
\hline Performance & Units of measurements & Value \\
\hline Total heated space area & {$\left[\mathrm{m}^{2}\right]$} & 3478.0 \\
\hline Total heated space volume & {$\left[\mathrm{m}^{3}\right]$} & 11477.0 \\
\hline Total enclosure structures area & {$\left[\mathrm{m}^{2}\right]$} & 1496.0 \\
\hline Transmission heat losses & \multirow{7}{*}[\mathrm{kW}\cdot\mathrm{h}/\text{year}]{} & 120094.6 \\
\hline Ventilation heat losses & & 25634.1 \\
\hline Total heat losses & & 145728.7 \\
\hline Internal heat losses & & 39089.9 \\
\hline Available solar heat gains & & 76627.2 \\
\hline Total heat gains & & 105677.1 \\
\hline Annual heat demand & & 40051.6 \\
\hline Specific annual heat demand & {$\left[\mathrm{kW} \cdot \mathrm{h} /\left(\mathrm{m}^{2} \cdot\right.\right.$ year $\left.)\right]$} & 11.52 \\
\hline Energy Efficiency Class & - & $\mathrm{A}^{+}$ \\
\hline
\end{tabular}

\section{Discussion}

The fundamental principle to design energy efficient unique building is a comprehensiveness of approach [22]. Detailed analysis of building form is necessary for creating of a passive house. Modeling of building geometry lets to considerate climatic factors that influence indirectly on energy efficiency of future structure. Form compactness, rational façades orientation, simple building geometry in plan are passive factors that reduce energy costs of building operation. Active measure is a designing of effective building envelope. Individual approach is necessary for designing of enclosure structures of buildings with unique architectural façades. It is necessary to consider each interface assemble of elements in details. However, it makes building process longer and more expensive. The solution of this problem can be using CAD and FEA technologies and creation of BIM-model also according to articles [23, 24]. Existence of BIM allows to control energy consumption and efficiency during whole building life cycle [25]. Besides, it will make certification of building with green standards (LEED, BREEAM) easier. Total obtainment of high energy efficiency class is possible with using of complex of engineering solutions: usage of renewable energy sources, heat pumps, reuse of water, smart house systems [26-33].

\section{Conclusion}

The base of unique buildings is an architectural component that creates just a shaping envelope, because of that the main aim of engineers and project designers becomes competent integration of energy efficiency standards and regulations with initial concept of future structure.

This paper includes actual researches in the area of thermal insulation of houses with unique façades. As a result, the suggestion of insulation of such constructions was offered. 
Detailed designing and thermal analysis allowed to create an effective thermal insulation of a building that is located in cold climate. Specific annual heat demand reached the value near $11.5 \mathrm{~kW} \cdot \mathrm{h} /\left(\mathrm{m}^{2} \cdot\right.$ year). It permits to classify this building to $\mathrm{A}+$ class (less than $15 \mathrm{~kW} \cdot \mathrm{h} /\left(\mathrm{m}^{2} \cdot\right.$ year $)$ for passive houses $)$, despite on unfavorable climatic conditions.

Eventually, complex of engineering solutions permitted to change from just architectural concept to complex system that creates comfort and safety of interior space.

\section{Appendix. Composition of enclosure structures}

Table 1. Materials used in the nodes A, B and C.

\begin{tabular}{|c|l|c|}
\hline № & $\begin{array}{l}\text { Name of enclosure structure } \\
\text { layer }\end{array}$ & $\begin{array}{c}\text { Thickness, } \\
\mathrm{mm}\end{array}$ \\
\hline 1 & reinforced coating & 95.0 \\
\hline 2 & Sand cement screed & 30.0 \\
\hline 3 & $\begin{array}{l}\text { Double-layer polyethylene } \\
\text { film }\end{array}$ & 1.5 \\
\hline 4 & Waterproof bitumen coating & 2.0 \\
\hline 5 & Primer & 1.0 \\
\hline 6 & Sand cement screed & 20.0 \\
\hline 7 & Roofing felt & 4.0 \\
\hline 8 & $\begin{array}{l}\text { Mineral wool thermal } \\
\text { insulation } \\
\text { (Isover OL-TOP+OL-Pe) }\end{array}$ & $30+300$ \\
\hline 9 & Sealant compound & 2.0 \\
\hline 10 & Vapour seal covering & 1.0 \\
\hline 11 & Primer & 1.0 \\
\hline 12 & Reinforced concrete slab & 200.0 \\
\hline
\end{tabular}

\begin{tabular}{|c|l|c|}
\hline № & $\begin{array}{l}\text { Name of enclosure structure } \\
\text { layer }\end{array}$ & $\begin{array}{c}\text { Thickness, } \\
\mathrm{mm}\end{array}$ \\
\hline 13 & $\begin{array}{l}\text { Eco-polymer composite } \\
\text { façade panel }\end{array}$ & 7.0 \\
\hline 14 & Air gap & 40.0 \\
\hline 15 & House wrap (Isover HB) & 1.0 \\
\hline 16 & Light gauge steel framing & 2.5 \\
\hline 17 & $\begin{array}{l}\text { Fiber-glass thermal insulation } \\
\text { (Isover VentFacade-Top) }\end{array}$ & 40.0 \\
\hline 18 & $\begin{array}{l}\text { Fiber-glass thermal insulation } \\
\text { (Isover VentFacade-Optima) }\end{array}$ & 50.0 \\
\hline 19 & $\begin{array}{l}\text { Fiber-glass thermal insulation } \\
\text { (Isover VentFacade-Bottom) }\end{array}$ & 250.0 \\
\hline 20 & $\begin{array}{l}\text { Fiber-glass thermal insulation } \\
\text { (Isover VentFacade-Optima) }\end{array}$ & 50.0 \\
\hline 21 & $\begin{array}{l}\text { Vapour seal covering } \\
\text { (Isover Vario/VS 80) }\end{array}$ & 1.0 \\
\hline 22 & Drywall & 24.0 \\
\hline 23 & Wall covering & 5.0 \\
\hline & \multicolumn{2}{|l}{} \\
\hline
\end{tabular}

\section{References}

1. United Nations Framework Convention on Climate Change (United Nations, Kyoto, 1997)

2. E. Enache-Pommer, R. Mayer, G. Parsons, ASHRAE Pap, 28, 1-9 (2013)

3. A. Gorshkov, X. Rakova, Proc. Eng, 100, 1505-1514 (2015)

4. W. Feist, Main provisions of the designing of passive houses (Ass. of Const. Univ, Moscow, 2008)

5. N. Vatin, D. Nemova, P. Rymkevich, A. Gorshkov, Mag. of Civ. Eng, 8, 4-14 (2012)

6. M. Tanic, D. Stankovic, V. Nikolic, M. Nikolic, D. Kostic, A. Milojkovic, S. Spasic, N. Vatin, Proc. Eng, 117, 924-937 (2015)

7. T. Egorova, V. Tscherkas, Bull. MGSU, 3-1, 421-428 (2011)

8. S. Sheina, A. Minenko, Analysis and calculation of thermal bridges for improvement of residential building's energy efficiency, Engineering Journal of Don. 4-1 (2012) 131.

9. T. Egorova, A. Fedotova, V. Tscherkas, P. Belogurov, Roof. and insul. Mat, 4, 26-32 (2013)

10. E. Varzaneha, M. Aminib, M. Bemanian, Proc. Eng, 94, 25-32 (2014) 
11. N. Kobelev, S. Emelyanov, V. Kretova, A. Morzhavin, V. Amelin, V. Kobelev, Proc. Eng, 117, 186-190 (2015)

12. V. Murgul, N. Vatin, I. Zayats, Proc. Eng, 117, 824-829 (2015)

13. A. Aksamija, Proc. Eng, 118, 72-80 (2015)

14. A. Nefedova, D. Chernyshev, D. Tseytin, Cons. of Un. Build. and Str, 10, 73-87 (2014)

15. S. Ovsyannikov, T. Vyazova, Roof. and insul. Mat, 1, 28-31 (2014)

16. L. Long, H. Ye, Ener. Proc, 75, 1850-1855 (2015)

17. A. Volkov, A. Sedov, Proc. Eng, 91, 362-367 (2014)

18. A.A. Aznabaev, A.V. Ovsyannikova, A.O. Povzun, Z.A. Gaevskaya, Cons. of Un. Build. and Str., 4(43), 103-116 (2016)

19. Building regulations SP 50.13330-2012 Thermal performance of the building (Scientific-Research institute of building physics of Russian architectural and building science, Moscow, 2013)

20. K. Lomas, R. Giridharan, Build. and Envir, 55, 57-72 (2012)

21. National code GOST R ISO 7730-2009 Ergonomics of the thermal environment. Analytical determination and interpretation of thermal comfort... (ANO "NIC KD", Moscow, Russia, 2010)

22. K. Gureev, A. Kazimirova, V. Avvakumov, G. Kafidov, P. Shaybacovich, A. Aznabaev, Sc.-meth. Elec. Jour. "Concept", 5, 76-80 (2014)

23. V. Bazjanac, IFC BIM-based methodology for semi-automated building energy performance simulation (Lawr. Berk. Nat. Lab., CA, USA, 2008)

24. M. Royapoor, T. Roskilly, Ener. and Build, 94, 109-120 (2015)

25. T. Lu, X. Lu, M. Viljanen, Ener. Proc, 75, 1825-1831 (2015)

26. N. Klueva, S. Emelyanov, V. Kolchunov, A. Bukhtiyarova, App. Mech. and Mat, 725726, 1423-1429 (2015)

27. V.L. Kvint, V.V Okrepilov, Herald of the Russian Academy of Sciences, 84 (3), 188 $200(2014)$

28. V.V Okrepilov, V.N. Krutikov, G.I. El'kin, Measurement Techniques, 57 (2),109-116 (2014)

29. V.V Okrepilov, A.Yu. Smirnov, Measurement Techniques, 56(1), 54-60 (2013)

30. V.V Okrepilov, Studies on Russian Economic Development, 24(1), 35-42 (2013)

31. V.V Okrepilov, Standarty i Kachestvo, 10, 52-55 (2005)

32. V.V Okrepilov, Ivanova, G. Standarty i Kachestvo, 12, 62-68. (2004)

33. V.V Okrepilov, Standarty i Kachestvo, 3, 94-96. (2003) 